\title{
PENERAPAN MODEL PEMBELAJARAN ARTIKULASI DALAM MENINGKATKAN HASIL BELAJAR AL-QUR'AN HADITS (Studi Pada Siswa Kelas VII B di MTs Thamrin Yahya Rambah Hilir)
}

\author{
Bashori \\ Dosen STAI Tuanku Tambusai Pasir Pengaraian \\ Email: bashoribashori@gmail.com
}

\begin{abstract}
Abstrak
Penelitian ini dilatarbelakangi oleh rendahnya hasil belajar Al-Qur;an Hadits siswa kelas VII B pada materi memahami isi kandungan surat Al-Kafirun dan AlBayyinah di MTs Thamrin Yahya Rambah Hilir Kabupaten Rokan Hulu. Subjek dalam penelitian ini adalah guru dan seluruh siswa kelas VII B yang berjumlah 30 orang siswa yang terdiri dari 14 orang siswa laki-laki dan 16 orang siswa perempuan. Sementara objek penelitian ini adalah penerapan model pembelajaran artikulasi untuk meningkatkan hasil belajar Al-Qur;an Hadits siswa kelas VII B pada materi memahami isi kandungan surat Al-Kafirun dan Al-Bayyinah di MTs Thamrin Yahya Rambah Hilir Kabupaten Rokan Hulu. Pengumpulan data dalam penelitian ini menggunakan teknik observasi dan tes hasil belajar. Hasil analisis data dapat disimpulkan bahwa penerapan model pembelajaran artikulasi dapat meningkatkan hasil belajar al-Qur'an Hadits siswa kelas VII B pada materi memahami isi kandungan surat al-Kafirun dan al-Bayyinah, dari rata-rata sebesar 63,33 pada sebelum tindakan menjadi 70,57 pada siklus I dan 78,03 pada siklus II. Hasil uji hipotesis diperoleh harga $\mathrm{t}_{\mathrm{o}}$ sebesar 18,631 jauh lebih besar dari nilai $\mathrm{t}_{\text {tabel }}$ pada taraf signifikan 5\% $(2,04)$ maupun pada taraf signifikan $1 \%(2,75)$. Dengan demikian hipotesis alternatif $(\mathrm{Ha})$ dapat diterima.
\end{abstract}

Kata Kunci: Model Pembelajaran, Artikulasi, Hasil Belajar, Al-Qur'an Hadits

\section{PENDAHULUAN}

Mata pelajaran al-Qur'an Hadits memiliki peran penting dalam rangka memberikan pendidikan kepada siswa untuk mencintai dan memahami al-Qur'an dan Hadis sebagai sumber ajaran Islam. Tujuan diberikannya mata pelajaran alQur'an Hadits di Madrasah Tsanawiyah antara lain: 1) Meningkatkan kecintaan siswa terhadap al-Qur'an dan Hadits; 2) Membekali siswa dengan dalil-dalil yang terdapat dalam al-Qur'an dan Hadits sebagai pedoman dalam menyikapi dan menghadapi kehidupan; dan 3) Meningkatkan kekhusyukan siswa dalam 
beribadah terlebih salat, dengan menerapkan hukum bacaan tajwid serta isi kandungan surat/ayat dalam surat-surat pendek yang mereka baca. ${ }^{1}$

Merujuk pada peran serta tujuan mata pelajaran al-Qur'an Hadits di atas, maka diperlukan pengelolaan pembelajaran dengan baik. Hal ini dilakukan agar para siswa dapat mencapai keberhasilan sesuai dengan tuntutan yang terkandung dalam tujuan di atas. Pengelolaan pembelajaran yang baik hanya akan tercipta manakala guru sadar akan peran dan fungsinya dalam memajukan pendidikan di sekolah.

Beberapa materi pembelajaran al-Quran Hadits kelas VII di Madrasah Tsanawiyah pada semester genap adalah tentang surat al-Kafirun dan alBayyinah. Salah satu bentuk kemampuan yang dipersyaratkan pada materi tersebut adalah siswa mampu memahami isi kandungan surat al-Kafirun dan alBayyinah dengan baik. Kedua surat ini secara spesifik mengajarkan tentang pentingnya toleransi dalam kehidupan, baik antara sesama muslim maupun antara umat beragama. Setelah mempelajari materi tersebut diharapkan siswa dapat menerapkan sikap toleran (tasamuh) di tengah-tengah kehidupan bangsa Indonesia yang memiliki keragaman suku, budaya, bahasa, dan agama.

Dalam menyajikan materi surat al-Kafirun dan al-Bayyinah di kelas VII B, guru telah berusaha semaksimal mungkin dengan menggunakan metode yang bervariasi seperti ceramah, hafalan, tanya jawab, dan latihan. Penggunaan metodemetode tersebut belum sesuai dengan harapan, dimana kebanyakan siswa kelas VII B masih merasa kesulitan dalam memahami materi yang disajikan guru.

Berdasarkan hasil pengamatan awal, beberapa kesulitan siswa terlihat dari hal-hal berikut ini: a) Sebagian siswa kelas VII B masih ada yang salah dalam menerjemahkan ayat-ayat maupun surat al-Kafirun dan al-Bayyinah secara keseluruhan; b) Sebagian siswa kelas VII B masih ada yang belum dapat menunjukkan bagian-bagian ayat dalam surat al-Kafirun dan al-Bayyinah yang berkaitan dengan toleransi; dan c) Sebagian siswa kelas VII B masih ada yang

\footnotetext{
${ }^{1}$ PERMENAG RI Nomor 000912 TAHUN 2013 Tentang Kurikulum Madrasah 2013 Mata Pelajaran Pendidikan Agama Islam dan Bahasa Arab, hlm. 26.
} 
belum dapat memahami isi kandungan surat al-Kafirun dan al-Bayyinah dengan baik.

Kesulitan-kesulitan siswa tersebut mengakibatkan pencapaian hasil belajar menjadi rendah. Dari 30 orang siswa kelas VII B yang memperoleh nilai di atas KKM sebesar 70 hanya 10 orang, sedangkan 20 orang siswa lainnya memperoleh nilai di bawah KKM.

Kesulitan-kesulitan siswa kelas VII B dalam memahami materi isi kandungan surat al-Kafirun dan al-Bayyinah di atas bukan tanpa sebab, namun ada sejumlah faktor yang mempengaruhinya. Menurut dugaan penulis, sejumlah faktor yang menyebabkan kesulitan-kesulitan siswa tersebut antara lain: 1) Proses penyajian materi kurang merangsang siswa untuk menggali materi secara lebih mendalam; 2) Penggunaan metode yang kurang sesuai dengan tujuan materi sehingga tidak dapat membantu siswa dalam memahami materi; 3) Aktivitas belajar siswa hanya sebatas membaca surat, mendengarkan penjelasan, dan mencatat materi; dan 4) Belum diterapkannya model pembelajaran yang dapat membantu siswa untuk memahami materi tersebut.

Merujuk pada kesulitan-kesulitan siswa dalam memahami materi surat alKafirun dan al-Bayyinah di atas, maka diperlukan upaya perbaikan pembelajaran dengan menerapkan model pembelajaran kooperatif yang sesuai dengan tujuan materi. Adapun salah satu model pembelajaran kooperatif yang dipilih adalah model pembelajaran artikulasi. Dengan menerapkan model pembelajaran artikulasi diharapkan dapat mengatasi kesenjangan antara proses dan hasil belajar siswa kelas VII B.

Menurut Aris Shoimin model pembelajaran artikulasi merupakan model pembelajaran yang menuntut siswa untuk bisa berperan sebagai penerima pesan sekaligus berperan sebagai penyampai pesan. ${ }^{2}$ Pembelajaran yang telah diberikan guru wajib diteruskan oleh siswa dan menjelaskannya kepada siswa lain di dalam pasangan kelompoknya. Sedangkan menurut Suprijono, model pembelajaran artikulasi merupakan model pembelajaran yang menuntut siswa aktif dalam

\footnotetext{
${ }^{2}$ Aris Shoimin, 68 Model Pembelajaran Inovatif 2013 (Yogyakarta:Ar-Ruzz, 2014), hlm. 27.
} 
pembelajaran dimana siswa dibentuk menjadi pasangan yang masing-masing siswa dalam pasangan tersebut mempunyai tugas mewawancarai teman pasangannya tentang materi yang baru dibahas. ${ }^{3}$

Dari beberapa pendapat di atas, dapat disimpulkan bahwa model pembelajaran artikulasi merupakan model pembelajarannya siswa dimana untuk menyampaikan materi yang diperoleh dari guru kepada pasangannya secara bergiliran. Dalam hal ini siswa dituntut untuk bisa berperan sebagai "penyampai pesan" sekaligus sebagai "penerima pesan." Dengan demikian, siswa tidak hanya dituntut untuk menjadi pendengar saja, tetapi juga diwajibkan untuk menyampaikan kembali materi yang didengarnya tersebut kepada teman pasangannya.

Dari kesimpulan tersebut terlihat bahwa model pembelajaran artikulasi menuntut keaktifan siswa aktif dalam pembelajaran. Para siswa saling berbagi pengetahuan secara aktif dengan cara mewancarai teman pasanganya tentang isi materi yang baru saja diterimanya. Dengan pembelajaran seperti ini diharapkan siswa dapat memahami isi kandungan surat al-Kafirun dan al-Bayyinah secara baik. Berdasarkan gejala-gejala yang telah diuraikan di atas, maka penulis merasa tertarik untuk mengadakan penelitian dengan penerapan model pembelajaran artikulasi untuk meningkatkan hasil belajar al-Qur'an Hadits.

\section{KAJIAN TEORI}

\section{Model Pembelajaran Artikulasi}

\section{a. Pengertian Model Pembelajaran Artikulasi}

Penerapan model-model pembelajaran menjadi suatu tuntutan yang harus dilaksanakan oleh para guru. Tuntutan tersebut lahir sebagai reaksi atas lemahnya proses pembelajaran di sekolah-sekolah yang hanya menitikberatkan pada pembelajaran tradisional. Pembelajaran tradisional cenderung berpusat kepada guru (teacher centred). Menurut Sanjaya pembelajaran yang berpusat kepada guru, penyampaian materi identik dengan menggunakan metode ceramah sebagai

\footnotetext{
${ }^{3}$ Agus Suprijono, Cooperative Learning Teori dan Aplikasi Paikem (Yogyakarta: Pustaka Pelajar, 2013), hlm. 127.
} 
metode utama, dan menempatkan siswa sebagai objek belajar yang harus menguasai materi pelajaran . $^{4}$

Penerapan model pembelajaran dipandang paling punya peran dalam upaya mendongkrak keberhasilan pembelajaran. Secara sederhana dapat dikatakan bahwa penggunaan dan penerapan model pembelajaran bergerak dengan melihat kondisi kebutuhan siswa, sehingga guru diharapkan mampu menyampaikan materi dengan tepat tanpa mengakibatkan siswa mengalami kebosanan.

Berbagai model pembelajaran telah dikembangkan secara intensif melalui berbagai penelitian, tujuannya untuk meningkatkan kerjasama akademik antar siswa, membentuk hubungan positif, mengembangkan rasa percaya diri, serta meningkatkan kemampuan akademik melalui aktivitas individu maupuh kelompok.

Model Pembelajaran dapat diartikan sebagai cara, contoh maupun pola, yang mempunyai tujuan meyajikan pesan kepada siswa yang harus diketahui, dimengerti, dan dipahami yaitu dengan cara membuat suatu pola atau contoh dengan bahan-bahan yang dipilih oleh para guru sesuai dengan materi yang diberikan. Menurut Trianto, model pembelajaran adalah kerangka konseptual yang melukiskan prosedur yang sistematis dalam mengorganisasikan pengalaman belajar untuk mencapai tujuan belajar dan berfungsi sebagai pedoman bagi para perancang pembelajaran dan para pengajar dalam merencanakan aktivitas belajat mengajar. ${ }^{5}$

Suprijono menjelaskan bahwa model pembelajaran adalah kerangka konseptual yang melukiskan prosedur sistematis dalam mengorganisasikan pengalaman belajar untuk mencapai tujuan belajar. ${ }^{6}$ Sedangkan menurut Syaiful Sagala, model pembelajaran adalah kerangka konseptual yang menggambarkan prosedur yang sistematis dalam mengorganisasikan pengalaman belajar peserta didik untuk mencapai tujuan belajar tertentu, dan berfungsi sebagai pedoman bagi

\footnotetext{
${ }^{4}$ Wina Sanjaya, Strategi Pembelajaran Berorientasi pada Standar Proses Pendidikan (Jakarta: Kencana, 2010), hlm. 97. 22

${ }^{5}$ Trianto, Mendesain Model Pembelajaran Inovatif-Progresif (Jakarta: Kecana, 2011), hlm.

${ }^{6}$ Agus Suprijono, Cooperative Learning Teori dan Aplikasi PAIKEM (Yogyakarta: Pustaka Pelajar, 2013), hlm. 46.
} 
perancang pembelajaran dan guru dalam merencanakan dan melaksanakan aktivitas belajar mengajar. $^{7}$

Berdasarkan beberapa pendapat di atas, maka dapat disimpulkan bahwa model pembelajaran merupakan suatu kerangka acuan yang digunakan dalam pembelajaran untuk mencapai tujuan tertentu. Artinya, model pembelajaran digunakan oleh guru sebagai pedoman dalam melaksanakan pembelajaran di kelas.

Salah satu dari berbagai model pembelajaran yang dapat diterapkan adalah model pembelajaran artikulasi. Menurut KBBI artikulasi artinya lafal atau pengucapan kata. ${ }^{8}$ Sedangkan menurut Kamus Bahasa Inggris, artikulasi berasal dari kata "articulate" yang artinya pandai berbicara, pandai mengeluarkan pikirannya. ${ }^{9}$ Menurut Aris Shoimin, model pembelajaran artikulasi merupakan model pembelajaran yang dalam prosesnya siswa dituntut untuk bisa berperan sebagai penerima pesan sekaligus berperan sebagai penyampai pesan. ${ }^{10}$ Sedangkan menurut Suprijono, model pembelajaran artikulasi merupakan model pembelajaran yang menuntut siswa aktif dalam pembelajaran dimana siswa dibentuk menjadi pasangan yang masing-masing siswa dalam pasangan tersebut mempunyai tugas mewawancarai teman pasangannya tentang materi yang baru dibahas. $^{11}$

Dari beberapa pendapat tersebut, dapat disimpulkan bahwa model pembelajaran artikulasi merupakan model yang proses pembelajarannya siswa diminta untuk menyampaikan materi yang didapatkan dari guru kepada pasangannya secara bergiliran. Dalam hal ini siswa dituntut untuk bisa berperan sebagai "penyampai pesan" sekaligus sebagai "penerima pesan." Dengan demikian siswa tidak hanya dituntut untuk menjadi pendengar saja, tetapi juga diwajibkan untuk menyampaikan kembali materi yang didengarnya tersebut kepada teman pasangannya. Dalam hal ini mereka saling berbagi pengetahuan hlm. 175 .

${ }^{7}$ Syaiful Sagala, Konsep dan Makna Pembelajaran (Bandung: Penerbit Alfabeta, 2010),

${ }^{8}$ Departemen Pendidikan Nasional, Kamus Besar Bahasa Indonesia (Jakarta: Balai Pustaka, 2005), hlm. 66.

${ }^{9}$ Jhon M. Echols dan Hassan Shadily, Kamus Inggris-Indonesia (Jakarta: PT. Gramedia Pustaka Utama, 2005), hlm. 39.

${ }^{10}$ Aris Shoimin, 68 Model Pembelajaran Inovatif..., hlm. 27.

${ }^{11}$ Agus Suprijono, Cooperative Learning Teori..., hlm. 127. 
secara aktif dengan cara mewancarai teman pasanganya tentang isi materi yang baru saja diterimanya. Dengan pembelajaran seperti ini diharapkan siswa dapat memahami isi kandungan surat al-Kafirun dan al-Bayyinah

\section{b. Sintaks Model Pembelajaran Artikulasi}

Menurut Aqib, sintaks atau langkah-langkah model pembelajaran Artikulasi adalah sebagai berikut: 1) Guru menyampaikan kompetensi yang ingin dicapai; 2) Guru menyajikan materi sesuai tujuan pembelajaran; 3) Untuk mengetahui daya serap siswa, bentuklah kelompok berpasangan dua orang; 4) Menugaskan salah satu siswa dari pasangan itu menceritakan materi yang baru diterima dari guru dan pasangannya mendengar sambil membuat catatan-catatan kecil, kemudian berganti peran. Begitu juga kelompok lainnya; 5) Menugaskan siswa secara bergiliran atau diacak menyampaikan hasil wawancaranya dengan teman pasangannya. Sampai sebagian siswa sudah menyampaikan hasil wawancaranya; 6) Guru mengulangi/menjelaskan kembali materi yang sekiranya belum dipahami siswa; dan 7) Kesimpulan/penutup. ${ }^{12}$

\section{c. Kelebihan dan Kelemahan Model Pembelajaran Artikulasi}

Menurut Barokah model pembelajaran artikulasi memiliki kelebihan dan kelemahan. Adapun kelebihan model pembelajaran artikulasi antara lain: 1) Semua siswa terlibat (mendapat peran); 2) Melatih kesiapan siswa; 3) Melatih daya serap pemahaman dari orang lain; 4) Cocok untuk tugas sederhana; 5) Interaksi lebih mudah; dan 6) Lebih mudah dan cepat membentuknya.

Sedangkan kelemahan model pembelajaran artikulasi antara lain: 1) Untuk mata pelajaran tertentu; 2) Waktu yang dibutuhkan banyak; 3) Materi yang didapat sedikit; 4) Banyak kelompok yang melapor dan perlu dimonitor; 5) Lebih sedikit ide yang muncul; dan 6) Jika ada perselisihan tidak ada penengah. ${ }^{13}$

${ }^{12}$ Zainal Aqib, Profesionalisme Guru Dalam Pembelajaran (Surabaya: Insan Cendekia, 2010), hlm. 22.

${ }^{13}$ Awalina Barokah, Model-Model Pembelajaran Kooperatif (Yogyakarta: Multi Pressindo, 2013), hlm. 78 . 


\section{Hasil Belajar}

\section{a. Pengertian Hasil Belajar}

Menurut Purwanto, hasil belajar dapat dijelaskan dengan memahami dua kata yang membentuknya, yaitu hasil dan belajar. Hasil merujuk kepada suatu perolehan akibat dilakukannya suatu aktivitas atas proses yang mengakibatkan berubahnya input secara fungsional. Sementara belajar merupakan upaya mengubah perilaku pada individu yang belajar. Dengan demikian, hasil belajar adalah perubahan yang mengakibatkan manusia berubah dalam sikap dan tingkah lakunya yang mencakup aspek kognitif, afektif dan psikomotorik. ${ }^{14}$

Sementara menurut Dimyati dan Mudjiono, hasil belajar adalah hasil yang diperoleh berupa kesan-kesan yang mengakibatkan perubahan dalam diri individu sebagai hasil dari aktivitas dalam belajar. ${ }^{15}$ Sedangkan menurut Sudjana, hasil belajar adalah kemampuan-kemampuan yang dimiliki peserta didik setelah menerima pengalaman belajarnya. ${ }^{16}$

Dari beberapa pendapat di atas maka dapat disimpulkan bahwa hasil belajar adalah bentuk-bentuk kemampuan yang dimiliki siswa setelah melalui tahapan pembelajaran yang ditunjukkan dengan nilai yang diberikan oleh guru. Bentukbentuk kemampuan tersebut meliputi kognitif, afektif maupun psikomotorik.

\section{b. Taksonomi Hasil belajar}

Menurut Bloom seperti yang kutip oleh Purwanto bahwa hasil belajar mencakup tiga ranah yaitu: kognitif, afektif, dan psikomotor. Ranah kognitif adalah ranah yang mencakup kegiatan mental (otak).. Dalam ranah kognitif itu terdapat enam jenjang proses berpikir yaitu pengetahuan (knowledge), pemahaman (comprehension), penerapan (application), analisis (analysis), sintesis (synthesis), dan penilaian (evaluation).

Selanjutnya ranah afektif adalah ranah yang berkaitan dengan sikap dan nilai. Ranah afektif dibagi menjadi lima jenjang, yaitu: receiving atau attending

\footnotetext{
${ }^{14}$ Purwanto, Evaluasi Hasil Belajar (Yogyakarta: Pustaka Pelajar, 2011), hlm. 45

${ }^{15}$ Dimyati dan Mujiono, Belajar dan Pembelajaran (Jakarta: Rineka Cipta, 2006), hlm.

${ }^{16}$ Nana Sudjana, Dasar-Dasar Proses Belajar Mengajar (Bandung: Sinar Baru Algesindo,
} 295. 2002), hlm. 22. 
(menerima atau memperhatikan), responding (menanggapi), valuing (menilai), organization (mengatur atau mengorganisasikan), characterization by a value or value complex (karakterisasi dengan suatu nilai atau komplek nilai).

Kemudian Ranah psikomotor adalah ranah yang berkaitan dengan keterampilan (skill) atau kemampuan bertindak setelah seseorang menerima pengalaman belajar tertentu yang memiliki enam tingkatan yaitu: persepsi (perception), kesiapan (set), gerakan terbimbing (guided response), gerakan terbiasa (mechanism), gerakan kompleks (adaptation), dan gerakan kreativitas (origination). ${ }^{17}$

Merujuk pada beberapa pendapat di atas, maka dapat disimpulkan bahwa hasil belajar merupakan perubahan tingkah laku setelah mengikuti pembelajaran yang dapat dilihat melalui tiga ranah yaitu kognitif, afektif maupun psikomotorik.

\section{c. Faktor-faktor yang Mempengaruhi Hasil Belajar}

Menurut Muhibbin Syah bahwa secara umum faktor-faktor yang mempengaruhi hasil belajar antara lain: Pertama, Faktor internal yang berasal dari dalam diri siswa meliputi dua aspek yaitu: 1) aspek fisiologis (yang bersifat jasmaniah) seperti kondisi jasmani dan tegangan otot serta tingkat kebugaran organ-organ tubuh dan sendi-sendinya, dapat mempengaruhi semangat dan intensitas siswa dalam mengikuti pelajaran, 2) aspek psikologis (yang bersifat rohaniah) seperti intelegensi atau tingkat kecerdasan, sikap, bakat, minat, dan motivasi siswa. Kedua, Faktor eksternal yang berasal dari luar diri siswa terdiri atas dua macam yaitu: 1) lingkungan sosial seperti para guru, para staf administrasi, dan teman-teman sekelas, masyarakat, tetangga, dan teman sepermainan di sekitar perkampungan siswa, 2) lingkungan non sosial seperti gedung sekolah, rumah, alat alat-alat belajar, keadaan cuaca, dan waktu belajar yang digunakan siswa. Dan Ketiga, Faktor pendekatan belajar yaitu jenis upaya belajar siswa yang meliputi model dan metode yang digunakan siswa untuk melakukan kegiatan mempelajari materi-materi pelajaran. ${ }^{18}$

\footnotetext{
${ }^{17}$ Purwanto, Evaluasi Hasil Belajar..., hlm. 51-53.

${ }^{18}$ Muhibbin Syah, Psikologi Pendidikan Suatu Pendekatan Baru (Jakarta: Rineka Cipta, 2010), hlm. 195.
} 
HIKMAH: Jurnal Pendidikan Islam Vol. 5, No. 2, Juli - Desember 2016

\section{Tinjauan Materi Memahami Isi Kandungan Surat al-Kafirun dan al- Bayyinah}

\section{a. Surat al-Kafirun dan Terjemahnya}

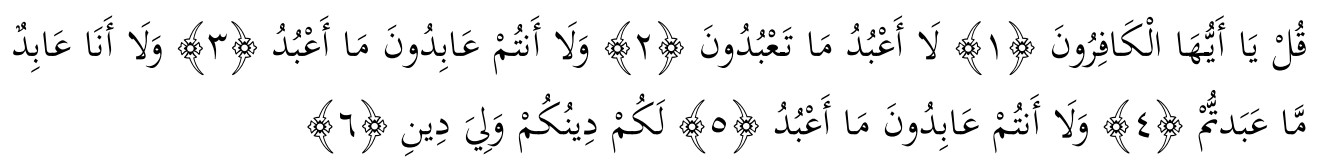

Atinya: Katakanlah: "Hai orang-orang kafir, Aku tidak akan menyembah apa yang kamu sembah, Dan kamu bukan penyembah Tuhan yang aku sembah, Dan aku tidak pernah menjadi penyembah apa yang kamu sembah, Dan kamu tidak pernah (pula) menjadi penyembah Tuhan yang aku sembah, Untukmu agamamu, dan untukkulah, agamaku."19

\section{b. Surat al-Bayyinah dan Terjemahnya}

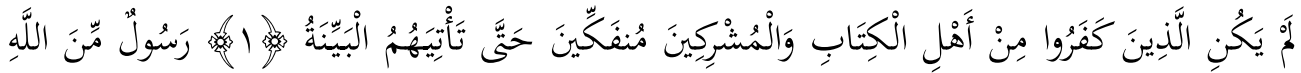

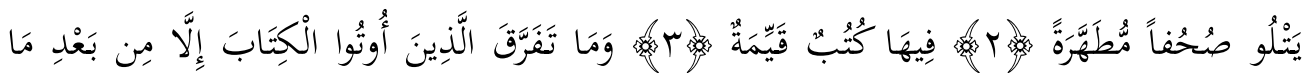

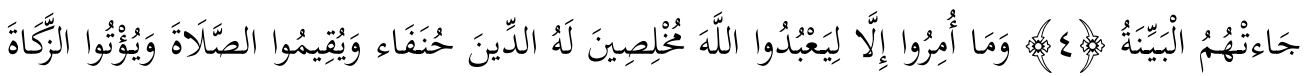

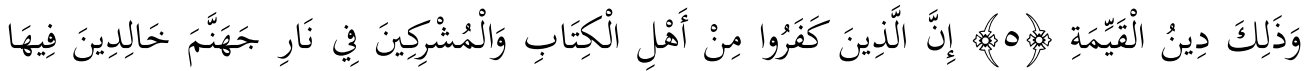

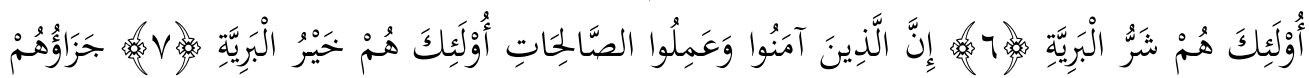

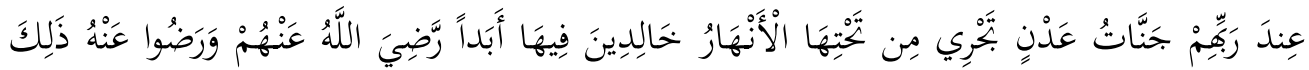

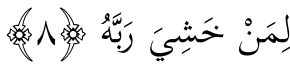
Artinya: Orang-orang kafir yakni ahli kitab dan orang-orang musyrik (mengatakan bahwa mereka) tidak akan meninggalkan (agamanya) sebelum datang kepada mereka bukti yang nyata, (yaitu) seorang Rasul dari Allah (Muhammad) yang membacakan lembaran-lembaran yang disucikan (Al Quran), Di dalamnya terdapat (isi) Kitab-Kitab yang lurus, Dan tidaklah berpecah belah orang-orang yang didatangkan Al kitab (kepada mereka) melainkan sesudah datang kepada mereka bukti yang nyata, Padahal mereka tidak disuruh kecuali supaya menyembah Allah dengan memurnikan ketaatan kepada-Nya dalam (menjalankan) agama yang lurus, dan supaya mereka mendirikan shalat dan

${ }^{19}$ Kementerian Agama RI, Al-Qur'an dan Terjemahnya (Jakarta: Dirjen Bimas Islam, 2012), hlm. 919. 
menunaikan zakat; dan yang demikian Itulah agama yang lurus, Sesungguhnya orang-orang yang kafir Yakni ahli kitab dan orang-orang yang musyrik (akan masuk) ke neraka Jahannam; mereka kekal di dalamnya. mereka itu adalah seburuk-buruk makhluk, Sesungguhnya orang-orang yang beriman dan mengerjakan amal saleh, mereka itu adalah Sebaik-baik makhlu, Balasan mereka di sisi Tuhan mereka ialah syurga 'Adn yang mengalir di bawahnya sungaisungai; mereka kekal di dalamnya selama-lamanya. Allah ridha terhadap mereka dan merekapun ridha kepadanya. yang demikian itu adalah (balasan) bagi orang yang takut kepada Tuhannya. ${ }^{20}$

\section{c. Isi Kandungan Surat al-Kafirun dan al-Bayyinah}

Surat al-Kafirun dan al-Bayyinah secara garis besar mengandung ajaran tentang toleransi. Toleransi adalah sikap suka menghargai, membiarkan, membolehkan pendirian (pendapat, pandangan, keyakinan, kebiasaan, kelakuan, dan sebagainya) yang berbeda atau bertentangan dengan pendiriannya sendiri. Dengan kata lain, toleran yaitu memberi kebebasan kepada orang lain untuk bersikap atau berpendirian sesuai dengan keinginannya. Konsep toleransi dalam Islam adalah tasamuh yang berarti memberi kemurahan dan keluasan.

Dalam konteks sosial, tasamuh akan sangat bermakna bagi kehidupan manusia, karena kemudahan dan kebebasan diberikan kepada orang lain untuk berfikiran yang berbeda dengan pemikirannya, melaksanakan ibadah yang berbeda dengan ibadah yang dilakukannya. Dengan demikian akan terjalin kehidupan yang harmonis dan saling menghargai dan menghormati satu sama lain.

Surat al-kafirun dan al-Bayyinah mempunyai keterkaitan sangat erat dan saling melengkapi. Keterkaitan kedua surat ini adalah adanya pengakuan terhadap keragaman agama sebagai sebuah keniscayaan hidup bermasyarakat. Pada kontek ini, islam menjujung tinggi perbedaa dan menyilahkan masing-masing untuk beribadah sesuai keyakinannya. Islam lebih lanjut memerintahkan untuk membangun kehidupan bermasyarakat dengan saling toleransi, saling menghormati, dan hidup rukun tanpa memaksakan suatu keyakinan kepada orang lain.

\footnotetext{
${ }^{20}$ Ibid., hlm. 907-908.
} 
Selain mengandung ajaran toleransi, surat al-Kafirun dan al-Bayyinah juga mengandung ajaran sikap fanatik. Dalam Kamus Besar bahasa Indonesia, fanatik artinya teramat kuat kepercayaan (keyakinan) terhadap ajaran (politik, agama dan sebagainya). ${ }^{21}$ Dengan demikian, orang yang fanatik dalam beragama berarti memiliki keyakinan yang kuat dan mantap dalam hati terhadap agamanya.

Ahmad Mustafa Al-Maraghi dalam tafsirnya menjelaskan bahwa surat alKafirun ini pada dasarnya merupakan bentuk penolakan atas ajakan kaum kafir Quraisy untuk saling menukar keyakinan. Hal ini dapat dilihat dari ringkasan tafsir ayat 1-2 bahwa bentuk ibadah antara umat islam dengan orang kafir sangat berbeda. Sebab orang kafir menggambarkan Tuhan dengan sifat-sifat yang tidak semestinya bagi Tuhan umat Islam. Pada ayat 3 menjelaskan bahwa terdapat perbedaan antara Tuhan orang-orang kafir dengan Tuhan umat Islam. Sesungguhnya orang-orang kafir itu bukanlah orang-orang yang berhak menyembah Tuhan yang disembah umat Islam. Karenanya, tidak mungkin menyamakan antara kedua Tuhan itu. Setelah menyanggah adanya persamaan dalam zat yang disembah, kemudian pada ayat 4-5 Allah menyanggah pula akan tidak adanya kesamaan dalam hal cara beribadah antara orang-orang kafir dan umat Islam. Ada perbedaan yang asasi dalam hal yang disembah dan cara beribadah. Selanjutnya pada ayat ke 6 Allah Swt memperingatkan orang-orang kafir bahwa mereka mempunyai balasan atas amal kalian, dan orang-orang Islam menerima balasan atas amalnya. ${ }^{22}$

Menurut Quraish Shihab, pada awal ayat al-Kafirun merupakan bentuk tanggapan atas usul kaum musyrikin untuk berkompromi akidah dan kepercayaan tentang Tuhan. Usul tersebut ditolak dan akhirnya ayat terakhir surah ini menawarkan bagaimana sebaiknya perbedaan tersebut disikapi. ${ }^{23}$ Sementara pada surah al-Bayyinah disebutkan bahwa orang-orang kafir menutupi kebenaran dengan tidak akan meninggalkan agama dan kepercayaannya sebelum dating

21 Departemen Pndidikan Nasional, Kamus Besar Bahasa Indonesia (Jakarta: Balai Pustaka, 2005), hlm. 313.

22 Ahmad Mustafa Al-Maraghi, Tafsir Al-Maraghi (Semarang: Karya Toha Putra, 1993), hlm. 47-448.

${ }^{23}$ M. Quraish Shihab, Tafsir Al-Misbah Pesan, Kesan dan Keserasian Al-Qur'an (Jakarta: Lentera Hati, 2002), hlm. 582. 
kepada mereka bukti yang nyata, yaitu Rasul yang dijanjikan Allah dan yang tercantum sifat-sifatnya dalam kitab suci kaum Yahudi dan Nasrani. Oleh karena itulah Allah Swt mengutus Nabi Muhammad Saw untuk membawa ajaran yang meluruskan kesesatan mereka. Namun sayangnya, sebagian mereka menerimanya dan sebagian lainnya tidak bahkan semakin meningkat kesesatannya. ${ }^{24}$

\section{METODE PENELITIAN}

\section{Jenis Penelitian}

Dalam penelitian ini, peneliti menggunakan jenis Penelitian Tindakan Kelas atau biasa disebut dengan PTK (Action Research). Penelitian tindakan kelas merupakan penelitian yang digunakan dalam rangka perbaikan aktifitas proses pembelajaran yang dilaksanakan antara guru dan murid. Oleh karena itu, dalam pelaksanaanya penelitian ini dilakukan di dalam kelas sebagai kegiatan penelitian tindakan.

\section{Waktu dan Lokasi Penelitian}

Penelitian ini membutuhkan waktu selama dua bulan terhitung Maret sampai dengan April 2016. Adapun lokasi dalam penelitian ini adalah di MTs Thamrin Yahya Rambah Hilir Kabupaten Rokan Hulu.

\section{Subjek dan Objek Penelitian}

Subjek dalam penelitian ini adalah guru dan para siswa kelas VII B yang berjumlah 30 orang siswa yang terdiri dari 14 orang siswa laki-laki dan 16 orang siswa perempuan. Sedangkan objek penelitian ini adalah penerapan model pembelajaran artikulasi dan hasil belajar al-Qur'an Hadits pada materi memahami isi kandungan surat al-Kafirun dan al-Bayyinah .

\section{Sumber Data}

Sumber data dalam penelitian ini terdiri dari dua sumber, yaitu: 1) Sumber yang berasal dari guru adalah untuk melihat tingkat keberhasilan penerapan model artikulasi; dan 2) Sumber yang berasal dari siswa adalah untuk melihat aktivitas belajar dan peningkatan hasil belajar al-Qur'an Hadits siswa kelas VII B pada materi memahami isi kandungan surat al-Kafirun dan al-Bayyinah.

\footnotetext{
${ }^{24}$ Ibid., hlm. 439-440.
} 


\section{Teknik Pengumpulan Data}

Teknik pengumpulan data yang digunakan dalam penelitian tindakan kelas ini adalah sebagai berikut:

\section{Observasi}

Observasi merupakan teknik mengumpulkan data dengan cara melakukan pengamatan dan pencatatan secara sistematik terhadap gejala yang tampak pada objek penelitian. ${ }^{25}$

Teknik observasi ini digunakan untuk mengamati aktivitas guru dalam pembelajaran dan aktivitas belajar siswa kelas VII B pada pembelajaran memahami isi kandungan surat al-Kafirun dan al-Bayyinah.

\section{Tes Hasil Belajar}

Tes adalah seperangkat rangsangan (stimulus) yang diberikan kepada seseorang dengan maksud untuk mendapatkan jawaban yang dapat dijadikan dasar penetapan skor angka. ${ }^{26}$ Dalam penelitian ini penulis menggunakan instrumen tes tertulis dengan bentuk pilihan ganda pada setiap siklusnya.

\section{Wawancara}

Wawancara adalah percakapan dengan maksud tertentu. Percakapan itu dilakukan oleh dua pihak, yaitu pewawancara (interviewer) yang mengajukan pertanyaan dan terwawancara (interviewee) yang memberikan jawaban atas pertanyaan itu. ${ }^{27}$ Teknik wawancara ini penulis gunakan untuk mendapatkan data tentang sejarah berdirinya MTs Thamrin Yahya Kecamatan Rambah Hilir Kabupaten Rokan Hulu.

\section{Dokumentasi}

Dokumentasi adalah mencari data mengenai hal-hal atau variabel yang berupa catatan, transkrip, buku, surat kabar, majalah, prasasti notulen rapat, lengger, agenda dan sebagainya. ${ }^{28}$ Teknik dokumentasi ini penulis gunakan untuk mendapatkan data-data yang berkaitan dengan keberadaan MTs Thamrin Yahya

\footnotetext{
${ }^{25}$ S. Margono, Metodologi Penelitian Pendidikan (Jakarta: Rineka Cipta, 2005), hlm. 158.

${ }^{26}$ M. Quraish Shihab, Tafsir Al-Misbah Pesan, Kesan dan Keserasian Al-Qur'an (Jakarta: Lentera Hati, 2002), hlm. 170.

${ }^{27}$ Lexy J. Moleong, Metode Penelitian Kualitatif (Bandung: Remaja Rosda Karya, 2005), hlm. 186.

${ }^{28}$ Suharsimi Arikunto, Manajemen Penelitian (Jakarta: Rinika Cipta), hlm. 206.
} 
Kecamatan Rambah Hilir Kabupaten Rokan Hulu, seperti struktur organisasi, laporan bulanan sekolah, dan kurikulum.

\section{Teknik Analisis Data}

Pada penelitian tindakan kelas ini, terdapat dua data yaitu data kualitatif dan kuantitatif. Data kualitatif dianalisis menggunakan teknik analisis deskriptif dengan persentase, sedangkan data yang bersifat kuantitatif disajikan dengan menggunakan uji statistik.

1. Aktivitas guru dianalisis menggunakan rumus persentase sebagai berikut:

$$
\text { Persentase }(\%)=\frac{\text { jumlah skor yang diperoleh }}{\text { skor maksimal }} \times 100 \%
$$

Aktivitas guru ditentukan dengan menggunakan kriteria sebagai berikut:
a. $80 \%-100 \%$ : Aktifitas guru baik sekali.
b. $70 \%-79 \%$ : Aktifitas guru baik.
c. $60 \%-69 \%$ : Aktifitas guru cukup.
d. $0 \%-59 \%$ : Aktifitas guru kurang.

2. Aktivitas belajar siswa kelas VII B dianalisis menggunakan rumus persentase sebagai berikut:

Persentase $(\%)=\frac{\text { jumlah skor yang diperoleh }}{\text { skor maksimal }} \times 100 \%$

Aktifitas belajar siswa kelas VII B ditentukan dengan menggunakan kriteria sebagai berikut:
a. $80 \%-100 \%$ : Aktifitas belajar siswa sangat baik
b. $70 \%-79 \%$ : Aktifitas belajar siswa baik.
c. $60 \%-69 \%$ : Aktifitas belajar siswa cukup.
d. $0 \%-59 \%$ : Aktifitas belajar siswa kurang.

3. Hasil belajar al-Qur'an Hadits siswa kelas VII B dianalisis menggunakan rumus rata-rata (mean) sebagai berikut:

$$
\mathrm{M}=\frac{\sum X}{N}
$$

Dimana :

$\mathrm{M}=$ Nilai rata-rata (mean)

$\mathrm{N}=$ Number of case (jumlah frekuensi / banyaknya individu) 
$\sum X=$ Jumlah nilai. $^{29}$

Hasil belajar siswa di atas dibagi ke dalam beberapa kategori sebagai beikut:

a. $80-100$ : hasil belajar siswa dikategorikan sangat tinggi.

b. $70-79$ : hasil belajar siswa dikategorikan tinggi.

c. $60-69$ : hasil belajar siswa dikategorikan cukup.

d. 0 - 59 : hasil belajar siswa dikategorikan rendah.

4. Uji hipotesis penelitian tindakan kelas ini menggunakan rumus "tes $t$ " sebagai berikut:

$$
t_{o}=\frac{\left(\frac{\sum D}{N}\right)}{\left(\frac{S D_{D}}{\sqrt{N-1}}\right)}
$$

Dimana:

$\sum \mathrm{D}=$ Selisih nilai antara pra tindakan dengan setelah tindakan

$\mathrm{SD}_{\mathrm{D}}=$ Standar deviasi antara pra tindakan dengan setelah tindakan.

$\mathrm{N}=$ Jumlah siswa. $^{30}$

\section{HASIL DAN PEMBAHASAN}

Analisis data ini dilakukan untuk melihat perbandingan pencapaian rata-rata belajar siswa kelas VII B antara sebelum dan sesudah dilakukan tindakan. Dalam menganalisis hasil belajar siswa kelas VII B tersebut, penulis menggunakan rumus yang telah ditetapkan sebelumnya yaitu:

$$
\mathrm{M}=\frac{\sum X}{N}
$$

Untuk memudahkan dalam menganalisis data hasil belajar siswa kelas VII $\mathrm{B}$, maka penulis rangkum dalam bentuk rekapitulasi hasil belajar siswa seperti yang terdapat pada Tabel IV. 12 diketahui bahwa sebelum tindakan diperoleh jumlah total nilai sebesar 1900 dengan rata-rata sebesar 63,33 dalam kategori cukup tinggi dan ketuntasan kelas mencapai 33,33\%. Setelah dilakukan tindakan pada siklus I diperoleh jumlah total nilai 2117 dengan rata-rata sebesar 70,57

\footnotetext{
${ }^{29}$ Hartono, Statistik Untuk Penelitian (Yogyakarta: Pustaka Pelajar, 2008), hlm. 34.

${ }^{30}$ Ibid, hlm. 181.
} 
dalam kategori tinggi dan ketuntasan kelas telah mencapai 66,67\%. Setelah dilakukan tindakan pada siklus II diperoleh jumlah total nilai sebesar 2341 dengan rata-rata sebesar 78,03 dalam kategori tinggi dan ketuntasan kelas mencapai $100 \%$.

Berdasarkan data yang telah diuraikan di atas menunjukkan bahwa adanya perbedaan hasil belajar siswa kelas VII B antara sebelum tindakan dengan setelah dilakukan tindakan pada siklus I dan siklus II.

\section{Uji Hipotesis}

Untuk menguji hipotesis yang telah dirumuskan sebelumnya, penulis menggunakan uji tes "t" dengan rumus sebagai berikut:

$$
t_{o}=\frac{\left(\frac{\sum D}{N}\right)}{\left(\frac{S D_{D}}{\sqrt{N-1}}\right)}
$$

Adapun proses ujian hipotesisnya adalah sebagai berikut:

1. Menghitung harga $t_{o}$

a. Menyiapkan tabel perhitungan untuk mencari $\sum D$ dan $\sum D^{2}$ sebagaimana terlihat pada tabel berikut ini:

TABEL IV. 13

PERHITUNGAN HARGA "T"

\begin{tabular}{|c|l|c|c|c|c|}
\hline No & \multicolumn{1}{|c|}{ Nama Siswa } & $\begin{array}{c}\text { Sebelum } \\
\text { Tindakan }\end{array}$ & $\begin{array}{c}\text { Setelah } \\
\text { Tindakan }\end{array}$ & D & $\mathbf{D}^{\mathbf{2}}$ \\
\hline 1 & Abuzar Al Gifari & 65 & 77 & -12 & 144 \\
\hline 2 & Aida Fitri & 70 & 77 & -7 & 49 \\
\hline 3 & Arvi Sanjaya & 60 & 77 & -17 & 289 \\
\hline 4 & Atifah Salsabila & 70 & 80 & -10 & 100 \\
\hline 5 & Badrul Wazi & 65 & 77 & -12 & 144 \\
\hline 6 & Bima Andesmar & 50 & 73 & -23 & 529 \\
\hline 7 & Diana Tantri & 65 & 77 & -12 & 144 \\
\hline 8 & Fadlan Minallah & 75 & 87 & -12 & 144 \\
\hline 9 & Fauzi Hidayatullah & 75 & 90 & -15 & 225 \\
\hline 10 & Fitri Lila Maya Sari & 70 & 83 & -13 & 169 \\
\hline 11 & Hadad Alwi & 60 & 77 & -17 & 289 \\
\hline 12 & Hayatun Nursida & 65 & 77 & -12 & 144 \\
\hline 13 & Hervina Ersa Fitri & 55 & 73 & -18 & 324 \\
\hline 14 & Jamaluddin & 65 & 77 & -12 & 144 \\
\hline
\end{tabular}


HIKMAH: Jurnal Pendidikan Islam Vol. 5, No. 2, Juli - Desember 2016

\begin{tabular}{|c|l|c|c|c|c|}
\hline 15 & Jumi Wulandari & 65 & 77 & -12 & 144 \\
\hline 16 & Lalan Alfindo & 50 & 73 & -23 & 529 \\
\hline 17 & M. Irvan & 50 & 73 & -23 & 529 \\
\hline 18 & M. Zikri & 65 & 80 & -15 & 225 \\
\hline 19 & Putri Balqis & 55 & 73 & -18 & 324 \\
\hline 20 & Rahmah & 60 & 77 & -17 & 289 \\
\hline 21 & Rahmat Hidayat & 70 & 80 & -10 & 100 \\
\hline 22 & Ria Sasmita & 75 & 87 & -12 & 144 \\
\hline 23 & Sella Afrilla & 55 & 73 & -18 & 324 \\
\hline 24 & Siti Azizah & 75 & 87 & -12 & 144 \\
\hline 25 & Sonia Putri Nasution & 70 & 80 & -10 & 100 \\
\hline 26 & Susilawati & 55 & 73 & -18 & 324 \\
\hline 27 & Tarmizi & 60 & 73 & -13 & 169 \\
\hline 28 & Tia Anggraini & 50 & 73 & -23 & 529 \\
\hline 29 & Zakiah & 65 & 77 & -12 & 144 \\
\hline 30 & Zahrul Akbar & 70 & 83 & -13 & 169 \\
\hline $\mathbf{N}=\mathbf{3 0}$ & & & -441 & 7025 \\
\hline
\end{tabular}

Berdasarkan Tabel IV. 13 di atas diperoleh $\mathrm{N}=30, \sum D=-441, \sum D^{2}=7025$.

b. Mencari standar deviasi perbedaan skor

$$
\begin{aligned}
S D_{D} & =\sqrt{\frac{\sum D^{2}}{N}}-\left(\frac{\sum D}{N}\right)^{2} \\
& =\sqrt{\frac{7025}{30}-\left(\frac{-441}{30}\right)^{2}} \\
& =\sqrt{234,167}-(-14,7)^{2} \\
& =\sqrt{234,167-216,090} \\
& =\sqrt{18,077} \\
S D_{D} & =4,252 .
\end{aligned}
$$

c. Substitusikan ke dalam rumus mencari $t_{0}$

$$
\begin{aligned}
t_{O} & =\frac{\left(\frac{\sum D}{N}\right)}{\left(\frac{S D_{D}}{\sqrt{N-1}}\right)} \\
& =\frac{\left(\frac{-441}{30}\right)}{\frac{4,252}{\sqrt{30-1}}}
\end{aligned}
$$




$$
\begin{gathered}
=\frac{-14,7}{\left(\frac{4,252}{\sqrt{29}}\right)} \\
=\frac{-14,7}{\left(\frac{4,252}{5,385}\right)} \\
=\frac{-14,7}{0,789} \\
t_{o}=-18,631
\end{gathered}
$$

2. Memberi interprestasi terhadap harga $t_{o}$

a. Mencari df

$$
\begin{aligned}
& \text { Df }=\mathrm{N}-1 \\
& \text { Df }=30-1=29
\end{aligned}
$$

b. Berkonsultasi pada tabel nilai"t".

Dengan $\mathrm{df}=29$ diperoleh harga kritik " $\mathrm{t}$ " atau $\mathrm{t}_{\text {tabel }}$ sebagai berikut:

Pada taraf signifikan 5\% $=2,04$

Pada taraf signifikan $1 \%=2,75$

c. Membandingkan harga $t_{o}$ dengan $t_{\text {tabel }}$ dengan ketentuan:

(1) Bila harga $t_{o}$ sama dengan atau lebih besar dari $t_{\text {tabel }}$ maka hipotesis nol $\left(\mathrm{H}_{\mathrm{o}}\right)$ ditolak yang berarti ada perbedaan yang dignifikan.

(2) Bila harga $t_{o}$ lebih kecil dari harga $t_{\text {tabel }}$ maka hipotesis nol $\left(\mathrm{H}_{\mathrm{o}}\right)$ diterima yang berarti tidak ada perbedaan yang signifikan.

Berdasarkan hasil uji hipotesis di atas dapat diketahui bahwa terdapat perbedaan yang signifikan hasil belajar siswa kelas VII B antara sebelum dan sesudah diterapkan model pembelajaran artikulasi dimana harga $t_{o}$ $(-18,631)$ jauh lebih besar dari nilai $t_{\text {tabel }}$ pada taraf signifikan $5 \%(2,04)$ maupun pada taraf signifikan $1 \%(2,75)$. Dengan hasil tersebut, maka dapat disimpulkan bahwa penerapan model pembelajaran artikulasi dapat meningkatkan hasil belajar al-Qur'an Hadits siswa kelas VII B pada materi memahami isi kandungan surat al-Kafirun dan al-Bayyinah di MTs Thamrin Yahya Rambah Hilir Kabupaten Rokan Hulu. 


\section{KESIMPULAN}

Berdasarkan hasil analisis data, maka dapat penulis simpulkan hasilnya sebagai berikut:

1. Aktivitas guru dan siswa kelas VII B dalam pembelajaran al-Qur'an Hadits pada materi memahami isi kanduangan surat al-Kafirun dan al-Bayyinah di MTs Thamrin Yahya Rambah Hilir Kabupaten Rokan Hulu menunjukkan adanya peningkatan pada setiap siklusnya. Berdasarkan hasil observasi, aktivitas guru dalam pembelajaran pada siklus I dikategorikan cukup baik dengan persentase skor sebesar 60\%, kemudian pada siklus II dikategorikan sangat baik dengan persentase skor sebesar 90\%. Sementara aktivitas belajar siswa kelas VII B pada siklus I dikategorikan baik dengan persentase sebesar $60 \%$ kemudian pada siklus II dikategorikan sangat baik dengan persentase skor sebesar $85,56 \%$.

2. Penerapan model pembelajaran Artikulasi dapat meningkatkan hasil belajar alQur'an Hadits siswa kelas VII B pada materi memahami isi kandungan surat al-Kafirun dan al-Bayyinah, dimana pada sebelum tindakan rata-rata hasil belajar siswa hanya mencapai 63,33 kemudian pada siklus I rata-rata hasil belajar siswa meningkat menjadi 70,57 dan 78,03 pada siklus II. Demikian juga dengan ketuntasan kelas (klasikal) mengalami peningkatan dari 33,33\% pada sebelum tindakan menjadi $66,67 \%$ pada siklus I, dan akhirnya mencapai $100 \%$ pada siklus. 


\section{DAFTAR KEPUSTAKAAN}

Agus Suprijono. Cooperative Learning Teori dan Aplikasi Paikem. Yogyakarta: Pustaka Pelajar. 2013.

Ahmadi, Abu., Joko Tri Prasetya. Strategi Belajar Mengajar Untuk Fakultas Tarbiyah Komponen MKDK, Bandung: Pustaka Setia. 2005.

Al-Maraghi, Ahmad Mushthafa. Tafsir Al-Maraghi, Semarang: Karya Toha Putra. 1993.

AM, Sardiman. Interaksi dan Motivasi Belajar Mengajar. Jakarta: PT. RajaGrafindo Persada. 2008.

Zainal Aqib. Profesionalisme Guru Dalam Pembelajaran. Surabaya: Insan Cendekia. 2010.

Awalina Barokah. Model-Model Pembelajaran Kooperatif. Yogyakarta: Multi Pressindo. 2013.

Departemen Pendidikan Nasional. Kamus Besar Bahasa Indonesia. Jakarta :Balai Pustaka 2005.

Dimyati dan Mujiono. Belajar dan Pembelajaran Jakarta: Rineka Cipta, 2006.

Hartono. Statistik Untuk Penelitian, Yogyakarta: Pustaka Pelajar. 2008.

Jhon M. Echols dan Hassan Shadily. Kamus Inggris-Indonesia, Jakarta: PT. Gramedia Pustaka Utama. 2005.

Kementerian Agama RI. 2014. Buku Siswa Al-Qur'an Hadis MTs Kelas VII, Jakarta: Kementerian Agama. 2014.

Margono. S. 2005. Metode Penelitian Pendidikan. Jakarta: Rineka Cipta. 2005.

Muhibbin Syah. Psikologi Pendidikan Suatu Pendekatan Baru. Jakarta: Rineka Cipta. 2010.

Nana Sudjana. Dasar-Dasar Proses Belajar Mengajar. Bandung: Sinar Baru Algesindo. 2002.

Purwanto. Evaluasi Hasil Belajar, Yogyakarta: Pustaka Pelajar. 2013.

Rusman. Model-Model Pembelajaran Mengembangkan Profesionalisme Guru. Jakarta: RajaGrafindo Persada. 2011. 
Shihab, M. Quraish. Tafsir Al-Misbah Pesan, Kesan dan Keserasian Al-Qur'an, Jakarta: Lentera Hati. 2002.

Syaiful Sagala. Konsep dan Makna Pembelajaran, Bandung: Alfabeta. 2010.

Trianto. Mendesain Model Pembelajaran Inovatif-Progresif. Jakarta: Kecana. 2011.

Wina Sanjaya. Strategi Pembelajaran Berorientasi pada Standar Proses Pendidikan. Jakarta: Kencana. 2010. 